\title{
Neoproterozoic Microfossils from the Margin of the East European Platform and the Search for a Biostratigraphic Model of Lower Ediacaran Rocks
}

\section{Citation}

Vorob'eva, Nataliya G., Vladimir N. Sergeev, and Andrew Herbert Knoll. 2009. Neoproterozoic microfossils from the margin of the East European Platform and the search for a

biostratigraphic model of lower Ediacaran rocks. Precambrian Research 173(1-4): 163-169.

\section{Published Version}

doi:10.1016/j.precamres.2009.04.001

\section{Permanent link}

http://nrs.harvard.edu/urn-3:HUL.InstRepos:3934555

\section{Terms of Use}

This article was downloaded from Harvard University's DASH repository, and is made available under the terms and conditions applicable to Open Access Policy Articles, as set forth at http:// nrs.harvard.edu/urn-3:HUL.InstRepos:dash.current.terms-of-use\#OAP

\section{Share Your Story}

The Harvard community has made this article openly available.

Please share how this access benefits you. Submit a story.

\section{Accessibility}




\title{
Neoproterozoic microfossils from the margin of the East European Platform and the search for a biostratigraphic model of lower Ediacaran rocks
}

\author{
N.G. Vorob'eva ${ }^{a}$, V.N. Sergeev ${ }^{a}$, A.H. Knoll ${ }^{\text {b* }}$ \\ Received 31 July 2008; received in revised form 31 December 2008; accepted \\ ${ }^{\text {a }}$ Geological Institute, Russian Academy of Sciences, Moscow, 109017, Russia \\ b,* Botanical Museum, Harvard University, Cambridge, Massachusetts, 02138, USA
}

\begin{abstract}
A ca. $600 \mathrm{~m}$ thick siliciclastic succession in northern Russia contains abundant and diverse microfossils that document early to middle Ediacaran deposition along the northeastern margin of the East European Platform. The Vychegda Formation is poorly exposed but is well documented by a core drilled in the Timan trough region (Kel'tminskaya-1 borehole). Vychegda siliciclastics lie unconformably above Tonian to lower Cryogenian strata and below equivalents of the late Ediacaran Redkino succession that is widely distributed across the platform. The basal ten meters of the formation preserve acritarchs and fragments of problematic macrofossils known elsewhere only from pre-Sturtian successions. In contrast, the upper, nearly $400 \mathrm{~m}$ of the succession contains abundant and diverse large acanthomorphic acritarchs attributable to the Ediacaran Complex Acanthomorph Palynoflora (ECAP). This distinctive set of taxa is known elsewhere only from lower, but not lowermost, Ediacaran rocks. In between lies an additional assemblage of relatively simple filaments and stratigraphically long ranging
\end{abstract}


sphaeromorphic acritarchs interpreted as early Ediacaran in age. Bearing in mind that knowledge of late Cryogenian (post-Strurtian/pre-Marinoan) microfossils is sparse, the Vychegda record is consistent with data from Australia and China which suggest that diverse ECAP microfossil assemblages appeared well into the Ediacaran Period. Accumulating paleontological observations underscore both the promise and the challenges for biostratigraphic characterization of the early Ediacaran Period.

Key words: Ediacaran, Vendian, Cryogenian, Upper Riphean, microfossil, acritarch, stratigraphy, East European Platform, Timan trough, Ural. 


\section{Introduction}

The Vendian succession of the East European Platform (EEP) has long played a key role in evolving ideas about terminal Proterozoic stratigraphy and evolution (Sokolov, 1984, 1997; Sokolov and Fedonkin, 1984). The Vendian type section comprises a platform succession deposited unconformably on top of crystalline basement, regionally distributed volcanic rocks, and Riphean aulacogen deposits. Across the platform, conglomerates interpreted as Laplandian glaciogenic rocks are overlain by Redkino sandstones, siltstones and argillites that contain a diverse biota of Ediacaran soft-bodied metazoans (Fedonkin, 1985, 1987). The Redkino and overlying Kotlin horizons (Regional Stages) also contain abundant microfossils, including filaments, small coccoidal cells and colonies, and sphaeromorphic acritarchs, but not the distinctive large acanthomorphic acritarchs recognized elsewhere in lower Ediacaran successions (Volkova et al., 1983; Burzin, 1994; Sokolov, 1997).

How much of Ediacaran time is recorded by these horizons? Radiometric constraints provide a sobering answer. The beginning of the Ediacaran Period is defined by a global stratigraphic section and point (GSSP) at the base of cap carbonates that

directly overlie glaciogenic rocks of the Elatina Formation in the Flinders Ranges, South Australia (Knoll et al., 2006b). U-Pb zircon dates on volcanic ash beds in correlative sections from China (Condon et al., 2005) and Namibia (Hoffmann et al., 2004) suggest an age of about 635 million years (Ma) for the beginning of the period (see Calver et al., 2004, for an alternative view). U-Pb zircon dates from Siberia (Bowring et al., 1993), 
Oman (Bowring et al., 2007) and Namibia (Grotzinger et al., 1995) also provide an age of $542 \pm 1$ Ma for the beginning of the subsequent Cambrian Period. Volcanic rocks of the Redkino succession in northern Russia have U-Pb zircon ages of 555.3 \pm 0.3 Ma near its top (Martin et al., 2000) and 558 \pm 1 Ma near its base (Grazhdankin, 2003), indicating that Vendian stratigraphy traditionally recognized above the Laplandian tillites records only the last $17 \%$ or so of the Ediacaran Period.

A sub-Redkino hiatus of substantial duration (Burzin and Kuz'menko, 2000) provides a reasonable explanation for the craton-wide absence of what Grey (2005) has called the Ediacaran Complex Acanthomorph Palynoflora, or ECAP. Conversely, the discovery of deposits containing diverse large and profusely ornamented acritarchs would identify a sub-Redkino Ediacaran record on the EEP. Here we discuss just such a record, recognized in borehole samples from the northeastern margin of the platform. These fossils fill in a key gap in our understanding of stratigraphic development on the EEP and extend our understanding of stratigraphic and evolutionary pattern at the beginning of the age of animals.

\section{Stratigraphic setting}

The Timan trough, located between the Russian and Timan-Pechora plates, contains thick upper Proterozoic and lower Paleozoic sedimentary successions complicated by numerous thrusts and folds (Fig. 1). There are few natural outcrops of 


\section{PLACE FIGURE 1 NEAR HERE}

the Proterozoic rocks in this region, so data about these successions comes mainly from boreholes. The paleontological discoveries discussed here come from the borehole "Kel'tminskaya-1," located near the Dzhezhim-Parma Uplift (Fig. 1).

Complicated geological structure and poor exposure of Neoproterozoic deposits within the Timan Uplift have resulted in competing stratigraphic schemes that sometimes use the same names in different ways. As an example, the Vychegda Formation, a key unit of this paper, differs in concept from the Vychegda subformation considered to be a lower member of the Ust'-Pinega Formation in adjacent areas of the Moscow syneclise (Stratigraphic dictionary, 1994). Stratigraphic subdivision of this borehole section is based on the Upper Proterozoic stratigraphic scheme of the adjacent Dzhezhim-Parma Uplift, as suggested by Tereshko and Kirillin (1990). Because the name Vychegda has consistently been applied to the relevant part of this borehole and its fossil contents, we follow precedent in retaining this name for our discussion.

The Kel'tminskaya-1 borehole (total depth $4902 \mathrm{~m}$ ) penetrates nearly $3600 \mathrm{~m}$ of Neoproterozoic strata in the Timan aulacogen, adjacent to the northeastern margin of the EEP (Fig. 2). The lower $2 \mathrm{~km}$ of core records a mixed carbonate-siliciclastic succession closely comparable to the earlier Neoproterozoic (Upper Riphean) Karatau Group in the Ural Mountains (Gechen et al., 1987; Raaben and Oparenkova, 1997; Sergeev, 2006a).

\section{PLACE FIGURE 2 NEAR HERE}


The upper kilometer of the Proterozoic section is, in turn, recognizable both lithologically and biostratigraphically as part of the Redkino and Kotlin successions observed across the EEP (Sokolov and Fedonkin, 1990) and can be traced into the adjacent Mezen syneclise (Fedonkin, 1981, 1987; Sokolov, 1997; Veis et al., 2004). Between these units lies the $600 \mathrm{~m}$ succession of the Vychegda formation. Like sedimentary successions on the EEP, the Vychegda succession is siliciclastic in its entirety. The lowermost part of the section contains coarse clastic lithologies interbedded with siltstones and shales. Above this, the formation fines upward from shoreface sandstones to siltstones and shales that record mid-shelf deposition. Unlike superjacent strata, the Vychegda Formation thins toward the Mesen syneclise (Fig. 3) and has no counterpart in that region. [For more information on the stratigraphy and tectonics of the adjacent Mezen syneclise, see Aplonov and Fedorov (2006) and Maslov et al. (2008).] Stratigraphic relationships, thus, constrain the Vychegda Formation to be younger than about 800 million years $(\mathrm{Pb}-\mathrm{Pb}$ dates on Uralian carbonates correlative with sub-Vychegda beds in the Kel'tminskaya-1 borehole; Ovchinnikova et al., 2000) and older than ca. 558 million years. Globally, this interval was a time of global ice ages (Hoffman and Schrag, 2002). Tillites are absent from the Kel'tminskaya-1 borehole, but probable Laplandian tillites occur in the nearby Poludov Ridge Uplift (Chumakov and Pokrovskii, 2007). Laplandian tillites have commonly been correlated with Marinoan deposits elsewhere (e.g., Sokolov and Fedonkin, 1984, 1990; Sokolov) 1997, but Chumakov (2008) has recently proposed that these glaciogenic beds may instead be Gaskiers equivalents, at least in part. This uncertainty does not affect hypotheses of age for fossiliferous Vychegda shales, as these depend solely on fossil content. Neither does it change the challenge of correlating ice 
ages with sequence boundaries in the Kel'tminskaya-1 borehole, as these should be eustatic responses to climate change, recorded globally.

\section{Fossil assemblages}

Vychegda shales are fossiliferous throughout the Kel'tminskaya-1 section, but the composition of assemblages changes systematically through the formation. Three distinct assemblages can be recognized. The lowermost Vychegda assemblage occurs only in the lowermost $10 \mathrm{~m}$ of the formation (borehole depths 2910-2900 m). It contains a moderate diversity of forms, including such typical Upper Riphean index taxa as Trachyhystrichosphaera aimika (Fig. 4t) and Prolatoforma aculeata (Fig. 4v), as well as sphaeromorphic and filamentous forms such as Chuaria circularis, Polytrichoides

oligofilum, Glomovertella eniseica, Ostiana microcystis, Caudosphaera expansa, Jacutionema solubila, Glomovertella eniseica, Leiosphaeridia spp., Siphonophycus spp. and others (Fig. 4l-q,s). The lowermost assemblage also contains numerous cuticle-like remains of the problematic carbonaceous macrofossil Parmia anastassiae (Fig. 4r) and Crinita unilaterata, an unusual microorganism of spheroidal shape, with long processes attached to one hemisphere only (Fig. 4u; Vorob'eva et al., 2009).

\section{PLACE FIGURE 3 NEAR HERE}


The middle assemblage (borehole depths 2899-2780 m) contains only remains of morphologically simple microorganisms: filaments, small coccoidal fossils, and spheromorphic acritarchs. It can be viewed as a taxonomic subset of the other assemblages, lacking both the biostratigraphically useful taxa that anchor the lowermost assemblage and the large, lavishly ornamented acritarchs that characterize upper Vychegda samples.

The upper two-thirds of the formation, from core depths of 2779 to $2312 \mathrm{~m}$, is the most distinctive of the three, containing abundant large acanthomorphic acritarchs comparable to those of the Pertatataka Formation, Australia, and other coeval assemblages. We refer to this as the "Kel'tma microbiota," distinguishing it from subjacent assemblages. The bulk of this assemblage comprises fossils of morphologically complex eukaryotic organisms, including previously described taxa such as Alicesphaeridium medusoideum, Tanarium conoideum, T. tuberosum, Cavaspina acuminata, and Appendisphaera aff. anguina (Fig. 4 a-c,e), as well as forms not previously reported (Fig. 4d, f-j; see Vorob'eva et al., 2009). The Kel'tma microbiota also contains morphologically simple filamentous and coccoidal microfossils of broad stratigraphic range, including Chuaria circularis, Polytrichoides oligofilum, Polysphaeroides filiformis, Elatera binata, Glomovertella eniseica, Leiosphaeridia spp., Siphonophycus spp., and some unusual morphotypes, such as large multilayered stalks made up of carbonaceous cones nested inside one another (Fig. 4k).

\section{PLACE FIGURE 4 NEAR HERE}


Diverse assemblages of large, morphologically complex acritarchs occur in the Pertatataka Formation, Amadeus Basin, Australia (Zang and Walter, 1992; Grey, 2005); the Ungoolya Group, Officer Basin, Australia (Jenkins et al. 1992; Grey, 2005; Willman et al., 2006); the Doushantuo Formation, China (Yuan et al., 2002, and references therein); the Scotia Group, Spitsbergen (Knoll, 1992); the Infrakrol Formation, India (Tiwari and Knoll, 1994); the Motta, Parshin, and Kursov formations, Siberia (Moczydlowska et al., 1993; Moczydlowska, 2005); the Biskopås Conglomerate, Norway (Vidal, 1990); and the Ura Formation, Patom Uplift, Siberia (Nagovitsyn et al., 2004; Vorob'eva et al., 2008; see also recent chemostratigraphic data of Pokrovskii et al., 2006, and Chumakov et al., 2007). Most of these assemblages lie above glaciogenic rocks considered correlative with those that subtend the Ediacaran System, and none have been interpreted as pre-Ediacaran. Where Ediacaran macrofossils occur in the same successions, they occur stratigraphically above beds that contain these distinctive acritarchs (Grey, 2005; Moczydlowska, 2005; Grey and Calver, 2007; Willman and Moczydlowska, 2008). Grey (2005; see also Grey and Calver, 2007) recognized four assemblage zones within the ECAP. The upper Vychegda assemblage resembles her lowermost $(\mathrm{Ab} / \mathrm{Am} / \mathrm{Gp})$ zone in that $A$. medusoideum is abundant, but it also contains Cavaspina acuminata, whose first appearance marks Grey's (2005) second assemblage zone.

\section{Discussion}


Radiometric dates are not available from the borehole, thus, hypotheses of age relationships necessarily rely on physical stratigraphy and fossil assemblages. The lowermost Vychegda assemblage compares closely with pre-Sturtian (Upper Riphean) microfossil assemblages elsewhere (e.g., Yankauskas, 1989; Knoll, 1996). A number of the taxa found in this assemblage were first described from the latest Mesoproterozoic Lakhanda Group, Siberia (Hermann, 1990), and nearly all have long stratigraphic ranges (Knoll, 1994; Butterfield, 2004, 2007). Key taxa such as T. aimika and P. anastassiae (and its close counterpart in China, the Protoarenicola/Pararenicola complex; Gnilovskaya, 1999; Gnilovskaya et al., 2000; Dong et al., 2008) have no well documented occurrences in post-Sturtian rocks. As Vychegda deposition apparently began after ca. $800 \mathrm{Ma}$ (Ovchinnikova et al., 2000), the basal $10 \mathrm{~m}$ of the section is most parsimoniously interpreted as Cryogenian in age. This interpretation could be falsified by the discovery of $T$. aimika and $P$. anastassiae in Ediacaran rocks or by postCryogenian ages in as yet unidentified lowermost Vychegda ash beds (U-Pb) or shales (Rh-Os)

In contrast, the uppermost Vychegda assemblage is parsimoniously interpreted as Ediacaran in age. Microfossil assemblages dominated by forms that combine large $(>100$ $\mu \mathrm{m})$ size; hollow processes; and symmetry in process distribution have, to date, been recovered only from Ediacaran rocks, and few if any of these taxa persist into the later Ediacaran interval characterized by diverse macrofossils (Knoll et al., 2006a). Taxonomic comparisons among Ediacaran assemblages are complicated by inherent biological variability, taphonomic history, preservational mode, and, apparently, rapid evolutionary turnover (Grey, 2005). Even when these factors have been taken into 
account, it is clear that the uppermost Vychegda assemblage contains forms not previously described from other localities. Nonetheless, it shares at least four morphospecies (Alicesphaeridium medusodieum, Cavaspina acuminata, Tanarium conoideum, and T. tuberosum) with ECAP assemblages in Australia, Siberia or both (Vorob'eva et al., 2009). The chief caveat in this interpretation is our limited understanding of microfossil assemblages in uppermost Cryogenian (post-Sturtian/preMarinoan) rocks. Again, our preferred interpretation could be falsified by radiometric age determinations or the discovery of diverse ECAP assemblages in pre-Ediacaran rocks; however, given that ECAP taxa appear to diversify well after the beginning of the Ediacaran Period and exhibit apparently rapid evolutionary turnover (Grey, 2005), we believe that the obvious and parsimonious interpretation will prove to be correct.

Accepting the lowermost Vychedga assemblage as Cryogenian and the uppermost assemblage as Ediacaran requires that later Cryogenian ice ages recorded globally (Hoffman and Schrag, 2002) must have come and gone during the interval bracketed by these fossils. As noted above, tillites do not occur in the Kel'tminskaya-1 borehole, so the signature of global glaciation must be sought in sequence boundaries governed by large amplitude sea level change (e.g., Hoffman et al., 2007). The obvious places to look are the unconformities that mark the lower and upper boundaries of the Vychegda Formation (Veis et al., 2006), but microfossils suggest that the upper unconformity is too young and the lower too old.

If we accept the most obvious biostratigraphic interpretations of Vychedga microfossils, we might circumvent the sequence boundary problem by interpreting the lowermost Vychedga assemblage differently, as survivors of Snowball glaciation. In 
Borehole 80 , however, $80 \mathrm{~km}$ to the north of the Kel'tminskaya-1 borehole, Parmiabearing strata considered equivalent to the lowermost Vychegda Formation are some 80 $m$ thick (the section is truncated by Quaternary deposits) and contain carbonate-rich horizons. This suggests that the basal $10 \mathrm{~m}$ of the Vychegda succession is a truncated succession separated from the remainder of the formation by a cryptic unconformity (Fig. 2) among the coarse non-marine to coastal marine clastic rocks recorded in the lower part of the Kel'tminskaya-1 borehole section (see Vorob'eva et al., 2006). Indeed, unless Vychedga microfossils have stratigraphic ranges distinctly different from similar assemblages elsewhere, simple stratigraphic logic requires that a cryptic unconformity exist somewhere in the borehole succession. Unconformities are common in coarse nonmarine successions, but are not easily detected, especially when observed in drill core.

In any case, the middle Vychegda Formation remains to be interpreted. Its low diversity of long ranging forms makes confident biostratigraphic interpretation challenging. However, given the biostratigraphic constraints on overlying and underlying beds, as well as the permissible points in the section for sequence boundaries, we propose that middle Vychedga microfossils may be early Ediacaran in age. This interpretation is consistent with data from Australia, where ECAP assemblages appear up to several hundred meters above Marinoan tillites, with simple microfossils assigned by Grey to the Ediacaran Leiosphere Palynoflora (Grey, 2005; Grey and Calver, 2007) in intervening beds. Grey (2002) noted that earlier Ediacaran microfossil assemblages "are poorly known but are similar to pre-glacial ones except that there are fewer species." Similarly, in China, diverse acanthomorphic acritarchs of the middle and upper Doushantuo Formation are preceded by simpler and less diverse microfossils, with uncommon 
acanthomorphs appearing just below an ash bed dated by U-Pb on zircons as $632.5 \pm 0.5$ million years (Condon et al., 2005; McFadden et al., 2006, 2008; Zhou et al., 2007; Yin et al. 2007).

Paleontological data, thus, imply that some but not all eukaryotic taxa survived late Neoproterozoic glaciation (Vidal and Knoll, 1982; see also Corsetti et al., 2006) some survivorship is mandated by crown groups members of eukaryotic phyla in preSturtian rocks, but extinction can be inferred only from biostratigraphy. Post-Sturtian but pre-Marinoan biology remains poorly documented, so it is hard to know whether inferred extinctions accompanied Sturtian or Marinoan glaciation. Available data also suggest that the major biological reorganization represented by ECAP microfossils occurred well after Marinoan deglaciation, in association with mid-Ediacaran redox change (Fike et al., 2006; Canfield et al., 2007; McFadden et al., 2008), animal radiation (Peterson and Butterfield, 2005; Yin et al., 2007), or the Acraman impact event (Grey et al., 2003). To the extent that at least some ECAP fossils preserve egg or diapause cysts of early metazoans (Yin et al., 2007), the ECAP radiation may signal the expansion of animals with resting stages in their life cycles (Marcus and Boero, 1998).

\section{Conclusions}

Regionally, then, Vychegda microfossils provide evidence for earlier Ediacaran deposition along the margin of but not on top of the EEP, filling the stratigraphic gap recognized earlier post-glacial rocks of the Vendian type section. Until now, the lack of paleontological or geochemical evidence for lower Ediacaran (Vendian) strata created 
uncertainties in the correlation of EEP successions to contemporaneous deposits throughout the world. By fitting between the Laplandian and Redkino horizons (Regional Stages) of the Vendian System type section, the Vychegda succession also invites formal establishment of a new Regional Stage that we propose to call the Vychegda Horizon. Fossils in this horizon document lower and middle Ediacaran micropaleontology in a clear fashion that complements data from Australia and China. While it is unlikely that Vychegda equivalents will be discovered on the well studied terrains of the EEP, they may turn out to be more widespread along passive margins of the platform.

Vychegda micropaleontology increases the known diversity and biogeographic heterogeneity of earlier Ediacaran fossil assemblages. And it adds support for hypotheses that relate some major changes in late Neoproterozoic biology to factors other than global glaciation. Indeed, the biostratigraphic succession preserved in the Vychegda succession provides one of our best views yet of biological change from the end of Marinoan glaciation until the radiation of macroscopic animals in the world's oceans. Continuing research will provide increasingly strong tests of hypotheses to explain mid-Ediacaran microfossil transition.

For now, the new acritarch assemblages provide additional perspective on attempts to characterize the lower boundary of the Ediacaran Period. The initial GSSPs for Phanerozoic periods were placed with reference to the first appearances of fossil animal species, a practice exported to the Proterozoic record only with difficulty. By international agreement, the GSSP for the initial boundary of the Ediacaran Period is placed with respect to major climatic and geochemical markers (Knoll et al., 2006b). 
Paleoclimate and geochemistry are likely to play key roles in both the subdivision of Ediacaran time and the downward extension of period boundaries defined by GSSP, but there is every reason to seek biostratigraphic events that can contribute to these efforts.

Available data suggest that most lower Ediacaran successions contain simple acritarchs and other long ranging species - a pattern reinforced by the paleontology of the Vychegda Formation. To date, only lower Ediacaran beds of the Doushantuo Formation, China, contain large acanthomorphic acritarchs of ECAP aspect, and these occur only as minor components of silicified assemblages (McFadden et al., 2006). In the absence of exceptional preservation or unusual environments, such rare acanthomorphs may be difficult to discover in other successions. Nonetheless, lower Ediacaran leiosphaerids and filaments - Grey's (2005) Ediacaran Leiosphere Palynoflora (ELP) assemblage zone - themselves differentiate lower Ediacaran strata when interpreted in the context of physical and chemical stratigraphy. Indeed, along with $\mathrm{C}$ and $\mathrm{Sr}$ isotopic data, microfossils suggest that three subdivisions of Ediacaran time might be recognizable internationally. The lowermost would be marked by two negative $\delta^{13} \mathrm{C}_{\text {carb }}$ excursions, with positive (+5\%) values in between (McFadden et al., 2008); ${ }^{87} \mathrm{Sr} /{ }^{86} \mathrm{Sr}$ values < 0.7083; and mostly simple microfossils (and rare large acanthomorphs). The middle would be based on (again) two negative $\delta^{13} \mathrm{C}_{\text {carb }}$ excursions, with positive $(+5 \%$ ) values in between (McFadden et al., 2008); ${ }^{87} \mathrm{Sr} /{ }^{86} \mathrm{Sr}$ values $>0.7083$ (Halverson et al., 2007); and abundant and diverse large acanthomorphic acritarchs. The last division combines a C-isotopic plateau of ca. 1-2\%o (Grotzinger et al., 1995), with a strong negative excursion at its end; ${ }^{87} \mathrm{Sr} /{ }^{86} \mathrm{Sr}$ values $>0.7083$; (again) simple acritarchs; widespread vendotaenids and other carbonaceous tube fossils; and a record of macroscopic animals that includes 
bilaterian body and trace fossils. Whether these three sets of geochemical and biological indicators change in concert and how they relate to Gaskiers glaciation and terminal Proterozoic redox change remain to be established. Taken together, however, geochemical, paleontological, and climatic signatures augur well for the confident subdivision of Ediacaran time and correlation of Ediacaran sedimentary rocks. Recognition of lower Ediacaran stratigraphy along the margin of the East European Platform brings us a step closer to this goal.

\section{Acknowledgments}

Research support in part by NSF grant EAR-0420592 and by RFBR Grants \# 0705-00457, \# 08-05-00429 and the Program of the Presidium of Russian Academy of Sciences \# 15. We thank two anonymous reviewers for helpful comments and M.A. Semikhatov, M.A. Fedonkin, V.N. Chumakov, W. Fischer, and P. Cohen for helpful discussion. 


\section{References}

Allison, C.W., Awramik, S.M., 1989. Organic-walled microfossils from earliest Cambrian or latest Proterozoic Tindir Group rocks, northwest Canada. Precambrian Res. 43, 253-294.

Aplonov, S.V., Fedorov, D.L., eds., 2006. Geodynamics and possible petroleum potential of the Mezen Sedimentary Basin. St. Petersburg, Nauka, 316 p. (In Russian).

Bowring, S., Grotzinger, J., Isaacson, G., Knoll, A.H., Pelachatty, S., Kolosov, P., 1993. Calibrating rates of early Cambrian evolution. Science 261, 1293-1298.

Bowring, S.A., Grotzinger, J.P., Condon, D.J., Ramezani, J., Newall, M.J., Allen, P.A., 2007. Geochronologic constraints on the chronostratigraphic framework of the Neoproterozoic Huqf Supergroup, Sultanate of Oman. Am. J. Sci. 307, 10971145.

Burzin, M.B., 1994. Principal trends in evolution of phytoplankton during the late Precambrian and earlier Cambrian. In: Ecosystem transformations and evolution of biosphere. Nauka, Moscow, pp. 51-62 (In Russian).

Burzin, M.B., Kuz'menko, T.Y., 2000. A high-resolution stratigraphic chart of the Vendian deposits in the Mezen Syneclise. Actual geological problems of mineral deposits in sedimentary basins, the European part of North Russia. Geoprint, Syktyvkar, 39-40. (In Russian).

Butterfield, N. J., 2004. A vaucherian alga from the middle Neoproterozoic of 
Spitsbergen: implications for the evolution of Proterozoic eukaryotes and the Cambrian explosion. Paleobiology 30, 231-252.

Butterfield, N. J., 2007. Macroevolution and macroecology through deep time. Palaeontology 50, 41-55

Calver, C.R., Black, L.P., Everard, J.L., Seymour, D.B., 2004. U-Pb zircon age constraints on late Neoproterozoic glaciation in Tasmania. Geology 32, 893896.

Canfield, D.E., Poulton, S.W., Narbonne, G.M., 2007. Late-Neoproterozoic deep-ocean oxygenation and the rise of animal life. Science 315, 92-95.

Chumakov, N.M., 2008. A problem of total glaciations on the Earth in the Late Precambrian. Stratigr. Geol. Correl. 16, 107-119.

Chumakov, N.M., Pokrovsky B.G., 2007. Vendian glacial deposits of the North and middle Urals: depositional environments and stratigraphical position. The Rise and Fall of the Vendian (Ediacaran) biota. Origin of the Modern Biosphere. Transaction of the International Conference on the IGCP Project 493. Geos, Moscow, 42-53.

Chumakov, N.M., Pokrovskii, B.G., Melezhik, V.A., 2007. Geological history of the Late Precambrian Patom Supergroup (Central Siberia). Dokl. Earth Sci. 413, 343-346.

Condon, D., Zhu, M., Bowring, S., Wang, W., Yang, A., Jin, Y., 2005. U-Pb ages from the Neoproterozoic Doushantuo Formation, China. Science 308, 95-98.

Corsetti, F.A, Olcott, A.N., Bakermans, C., 2006. The biotic response to Neoproterozoic snowball Earth. Palaeogeogr. Palaeoclimatol. Palaeoecol. 232, 114-130. 
Dong. L., Xiao, S., Shen, B., Yuan, X., Yan, X., Peng, Y., 2008. Restudy of the wormlike carbonaceous compression fossils Protoarenicola, Pararenicola, and Sinosabellidites from early Neoproterozoic successions in North China. Palaeogeogr. Palaeoclimatol. Palaeoecol. 258, 138-161.

Fedonkin, M.A., 1985. Non-skeletal fauna of the Vendian: promorphological analysis. In: Sokolov, B.S., Iwanoswki, A.B. (Eds.), The Vendian System, 1. Paleontology. Nauka, Moscow, 10-60. (In Russian; English version published in 1990 by Springer Verlag)

Fedonkin, M.A., 1987. Non-skeletal fauna of the Vendian and its place in the evolution of metazoans. Trudy Paleontol. Inst. Akad. Nauk SSSR 226, 1-173.

Fike, D.A., Grotzinger, J.P., Pratt, L.M., Summons, R.E., 2006. Oxidation of the Ediacaran ocean. Nature 444, 744-747.

Gechen, V.G., Dedeev, V.A., Bashilov, V.I. et al., 1987. Riphean and Vendian of the European North of the USSR. Oblknigoizdat,Vologda, 186 p. (In Russian). Gnilovskaya, M.B., 1998. Oldest annelidomorphs of the Upper Riphean from the Timan. Dokl. Earth Sci. 359, 369-372.

Gnilovskaya, M.B., Veis, A.F., Bekker, Y.R., Olovyanishnikov, V.G., Raaben. M.E., 2000. Pre-Ediacaran fauna from Timan (Annelidomorphs of the Late Riphean). Stratigr. Geol. Correl. 8, 11-39.

Grotzinger, J. P., Bowring, S.A., Saylor, B.Z., Kaufman, A.J., 1995. Biostratigraphic and geochronologic constraints on early animal evolution. Science 270, 598-604. 
Gradstein, F.M., Ogg, J., Smith, A.G. (Eds.). 2004. A Geologic Time Scale 2004. Cambridge University Press, Cambridge UK, 589 p.

Grazhdankin, D.V., 2003. Structure and depositional environment of the Vendian Complex in the southeastern White Sea area. Stratigr. Geol. Correl. 11, 313-331.

Grey, K., 2002. Surviving snowball Earth: Australia's acritarch record. GSWA 2002 Extended Abstracts, 8-9.

Grey, K., 2005. Ediacaran palynology of Australia. Mem. Assoc. Australas. Palaeontol. $31,1-439$.

Grey, K., Calver, C.R., 2007. Correlating the Ediacaran of Australia. The rise and fall of the Ediacaran biota. Geol. Soc. London Spec. Publ. 286, 115-135.

Grey, K., Walter, M.R., Calver, C.R., 2003. Neoproterozoic biotic diversification: Snowball Earth or aftermath of the Acraman impact? Geology 31, 459-462.

Halverson, G.P., Dudás, F.Ö., Maloof, A.C., Bowring, S.A., 2007. Evolution of the 87Sr/86Sr composition of Neoproterozoic seawater. Palaeogeogr. Palaeoclimatol. Palaeoecol. 256, 103-129.

Hermann, T.N., 1990. Organic world a billion years ago. Nauka, Leningrad, 50 p. (In Russian, with English summary).

Hoffman, P.F., Schrag, D.P., 2002. The snowball Earth hypothesis: testing the limits of global change. Terra Nova 14, 129-155.

Hoffman, P.F., Halverson, G.P., Domack, E.W., Husson, J.M., Higgins, J.M., Schrag, D.P., 2007. Are basal Ediacaran (635 Ma) post-glacial "cap dolostones" 
diachronous? Earth Planet. Sci. Lett. 258, 114-131.

Hoffmann, K.-H., Condon, D.J., Bowring S.A., Crowley, J.L., 2004. A U-Pb zircon age from the Neoproterozoic Ghaub Formation, Namibia: Constraints on Marinoan glaciation. Geology 32, 817-820.

Jenkins, R.J.F., McKirdy, D.M., Foster, C.B., O’Leary, T., Pell, S.D., 1992. The record and stratigraphic implications of organic-walled microfossils from the Ediacaran (terminal Proterozoic) of South Australia. Geol. Mag. 129, 401-410.

Knoll, A.H., 1992, Vendian microfossils in metasedimentary cherts of the Scotia Group, Prins Karls Forland, Svalbard. Palaeontology 35, 751-774.

Knoll, A.H., 1994. Proterozoic and Early Cambrian protists: evidence for accelerating evolutionary tempo. Proc. Nat. Acad. Sci., USA 91, 6743-6750.

Knoll, A.H., 1996. Archean and Proterozoic paleontology. In: Jansonius, J., McGregor, D.C. (Eds.), Palynology: principles and applications: Tulsa, American Association of Stratigraphic Palynologists Foundation 1, 51-80.

Knoll, A.H., Javaux, E.J., Hewitt, D., Cohen, P., 2006a. Eukaryotic organisms in Proterozoic oceans. Phil. Trans. Roy. Soc., London 361B, 1023-1038.

Knoll, A.H., Walter, M.R., Narbonne, G., Christie-Blick, N., 2006b. The Ediacaran Period: A new addition to the geologic time scale. Lethaia 39, 13-30.

Marcus, N.H., Boero, F. 1998. Minireview: The importance of benthic-pelagic coupling and the forgotten role of life cycles in coastal aquatic systems. Limnol. Oceanogr $43,763-768$. 
Martin, M.W., Grazhdankin, D.V., Bowring, S.A., Evans, D.A.D., Fedonkin, M.A., Kirschvink, J.L., 2000. Age of Neoproterozoic bilatarian body and trace fossils, White Sea, Russia: Implications for metazoan evolution. Science 288, 841845.

Maslov, A.V., Grazhdankin, D.V., Podkovyrov, V.N., Ronkin, Yu.L., Lepikhina, O.P., 2008. Composition of sediment provenances and patterns in geological history of the Late Vendian Mesen Basin. Lithology and Mineral Resources 43, 260-280.

McFadden, K.A, Xiao, S, Zhou, C., Xie, G., Schiffbauer, J.D., 2006. DoushantuoPertatataka acritarchs in Ediacaran successions of South China: preservational bias or ecological control? Geol. Soc. Am. Abstr. Progr. 38 (7), 303.

McFadden, K.A., Huang, J., Chu, X.L., Jiang, G.Q., Kaufman, A.J., Zhou, C.M., Yuan, X., Xiao, S., 2008. Pulsed oxidation and biological evolution in the Ediacaran Doushantuo Formation. Proc. Nat. Acad. Sci., USA, 105, 3197-3202.

Moczydlowska, M., 2005. Taxonomic review of some Ediacaran acritarchs from the Siberian Platform. Precambrian Res. 136, 283-307.

Moczydlowska, M., Vidal. G., Rudavskaya, V.A., 1993. Neoproterozoic (Vendian) phytoplankton from the Siberian Platform, Yakutia. Palaeontology 36, 495521.

Nagovitsyn, K.E., Faizullin, M.Sh., Yakshin, M.S., 2004. New forms of Baikalian acanthomorphytes from the Ura Formation of the Patom Uplift, East Siberia. Geologiya e Geofisika 45, 7-19. (In Russian) 
Ovchinnikova, G.V., Vasil'eva, I.M., Semikhatov, M.A., Gorokhov, I.M., Kuznetsov, A.B, Gorokhovskii, B.M., Levskii. L.K., 2000. The Pb-Pb trail dating of carbonates with open U-Pb systems: The Min'yar Formation of the Upper Riphean stratotype, southern Urals. Stratigr. Geol. Correl. 8, 529-543.

Peterson, K.J., Butterfield, N.J., 2005. Origin of the Eumetazoa: Testing ecological predictions of molecular clocks against the Proterozoic fossil record. Proc. Nat. Acad. Sci., USA 102, 9547-9552.

Pokrovskii, B.G., Melezhik, V.A. Bujakaite, M.I., 2006. Carbon, Oxygen, Strontium, and Sulfur Isotopic Compositions in Late Precambrian Rocks of the Patom Complex, Central Siberia: Communication 1. Results, Isotope Stratigraphy, and Dating Problems. Lithology and Mineral Resources 41 (5), 450-474.

Raaben, M.E., Oparenkova, L.I., 1997. New data on the Riphean Stratigraphy of Timan. Stratigr. Geol. Correl. 14, 368-385.

Sergeev, V.N., 2006a. Precambrian microfossils in cherts: their Paleobiology, classification, and biostratigraphic usefulness. Moscow, GEOS, 280 p. (In Russian)

Sergeev, V.N. 2006b. The importance of Precambrian microfossils for modern biostratigraphy. Paleontologicheskii Journal, 40:664-673.

Sokolov, B.S., 1984. The Vendian System and its position in the stratigraphic scale. Proceedings of the 27th International Geological Congress (Stratigraphy) 1, 241269. 
Sokolov, B.S., 1997. Essays on the establishment of the Vendian System. Moscow, KMK Scientific Press, 1-153 (in Russian)

Sokolov, B.S., Fedonkin, M.A., 1984. The Vendian as the Terminal System of the Precambrian. Episodes 7, 12-19.

Sokolov, B.S., Fedonkin, M.A., eds., 1990. The Vendian System. Volume 2, Regional geology. Berlin, Springer-Verlag, 1-277.

Stratigraphic dictionary: Upper Precambrian (Northern Eurasia in the boundaries of the former USSR). Moscow, Nauka, 351 p. (In Russian)

Tereshko, V.V., Kirillin, S.I., 1990. New data on Upper Proterozoic Stratigraphy of the Southern Timan, p. 81-82. The Upper Proterozoic Stratigraphy of the USSR (Riphean and Vendian). AN SSSR Scientific Publisher, Ufa (In Russian).

Tiwari, M., Knoll, A.H., 1994. Large acanthomorphic acritarchs from the Infrakrol Formation of the Lesser Himalayas and their stratigraphic significance. Himalayan Geol. 5, 193-201.

Veis, A.F., Fedorov, D.L., Kuzmenko, Y.T., Vorob'eva, N.G., Golubkova, E.Y., 2004. Microfossils and Riphean Stratigraphy in the North European Platform (Mezen Syneclise). Stratigr. Geol. Correl. 12, 16-35.

Veis, A.F., Vorob'eva, N.G., Golubkova, E.Yu., 2006. The Early Vendian Microfossils First Found in the Russian Plate: Taxonomic Composition and Biostratigraphic Significance. Stratigr. Geol. Correl. 14, 368-385.

Vidal, G., 1990. Giant acanthomorph acritarchs from the upper Proterozoic in southern Norway. Palaeontology 33, 287-298.

Vidal, G., Knoll, A.H., 1982. Radiations and extinction of plankton in the late 
Proterozoic and early Cambrian. Nature 297, 57-60.

Volkova, N.A., Kirjanov, V.V. Piskun, L.V., Paskeviciene, L.T., Jankauskas, T.V., 1983. Plant microfossils. In: Urbanek, A., Rozanov, A.Yu. (Eds.), Upper Precambrian and Cambrian Palaeontology of the East-European Platform. Publishing House Wydawnictwa Geologiczne, Warsaw, Poland, pp. 7-45.

Vorob'eva, N.G., Sergeev, V.N., Semikhatov, M.A., 2006. Unique Lower Vendian Kel'tma microbiota, Timan Ridge: new evidence for the paleontological essence and global significance of the Vendian System. Dokl. Earth Sci. 410, 1038-1043.

Vorob'eva, N.G., Sergeev, V.N., Chumakov, N.M., 2008. New Finds of Early Vendian Microfossils in the Ura Formation: Revision of the Patom Supergroup Age, Middle Siberia. Dokl. Earth Sci. 419, 782-787.

Vorob'eva, N.G., Sergeev, V.N., Knoll, A.H., 2009. Neoproterozoic microfossils from the Northeastern margin of the East European Platform. J. Paleontol. 83: 161-192.

Willman, S., Moczydlowska, M., 2008. Ediacaran acritarch biota from the Giles 1 drillhole, Officer Basin, Australia, and its potential for biostratigraphic correlation. Precambrian Res. 162, 498-530.

Willman, S., Moczydlowska, M., Grey, K., 2006. Neoproterozoic (Ediacaran) diversification of acritarchs - a new record from the Munaroo 1 drillcore, eastern Officer Basin, Australia. Rev. Palaeobot. Palynol. 139, 17-40.

Yankauskas, T.V., ed., 1989. Mikrofossilii dokembrya SSSR (Precambrian microfossils of the USSR), 1989. Trudy Instituta Geologii i Geochronologii Dokembria SSSR Akademii Nauk, Leningrad, 188 p. (In Russian). 
Yin, L., Zhu, M., Knoll, A. H., Yuan, X., Zhang, J., Hu, J, 2007. Doushantuo embryos preserved inside diapause egg cyst. Nature 446, 661-663.

Yuan, X., Xiao, S., Yin, L., Knoll, A.H., Zhou, C.M., Mu, X., 2002. Doushantuo Biota: A Window on Early Multicellular Life. Chinese Scientific and Technological University Press, Shengzhen, China, 171 p. (In Chinese)

Zang, W., Walter, M.R., 1992. Late Proterozoic and Cambrian microfossils and biostratigraphy, Amadeus Basin, central Australia: Mem. Assoc. Australas. Palaeontol. 12, 1-132.

Zhou, C., Xie, G., McFadden, K., Xiao, S., Yuan, X., 2006. The diversification and extinction of Doushantuo-Pertatataka acritarchs in South China: causes and biostratigraphic significance. Geol. J. 42, 229-262. 


\section{FIGURE CAPTIONS}

Figure 1. Location map of the Kel'tminskaya-1 borehole in the Timan Ridge, marginal to the East European Platform, and the Nyaftyanskaya -21 borehole in the Mesen syneclise; black indicates areas of Proterozoic outcrop along the ridge.

Figure 2. Stratigraphic section of the Kel'tminskaya-1 borehole showing major stratigraphic units, lithologies, and the positions of the lower (LA), middle (MA) and upper (UA) Vychegda microfossil assemblages. Key (to fig. 2 and fig. 3): 1- limestones and dolomites, 2 - dolomites with cherts, 3 - shales, 4 - siltstones, 5 - gravelstones and sandstones, 6 - conglomerates, 7 - stromatolitic carbonates; 8 - unconformities observed or proposed; 9 - metamorphic basement; 10 - upper Ediacaran soft-bodied metazoans (Belomorian biota). Abbreviations of formation and horizon names: U-Pn, Ust'- Pinega; Ks, Krasavin; Mz, Mezen; Pd, Padun; Uf, Uftyug; Tf, Tamitsa; Red., Redkino Horizon (Regional Stage). The most probable position of the basal Ediacaran Boundary is considered to lie between the lower and middle microfossil assemblages; an alternative placement, at the sub-Vychegda unconformity, is indicated by a dashed line and question mark. 
Figure 3. Correlation of the Kel'tminskaya-1 borehole section with the Mezen syneclise succession, Nyaftyanskaya-21 borehole (after Veis et al., 2004). See Fig. 1 for locations and Fig. 2 for key and abbreviations. The Vychedga Formation has no equivalent in classic EEP stratigraphy; its thickness is thought to decline toward the Mezen syneclise (filled triangule). Formation names are given to the left of stratigraphic columns.

Figure 4. Microfossils from the Vychegda Formation. a - Alicesphaeridium medusoideum; $\mathrm{b}$ and $\mathrm{c}$ - Alicesphaeridium spp.; $\mathrm{d}$ - unnamed form with complex processes; e - Tanarium conoideum; f - unnamed vesicle with spheroidal (?) processes between outer and inner wall layers; $\mathrm{g}$ - unnamed form with hemispherical processes; $\mathrm{h}$ unnamed form with long cylindrical processes marked by bulbous tips; i - unnamed form with two processes that arise from opposite poles; $\mathrm{j}$ - spherical vesicles with medial split; k- multilayered stalks built from cones nested one inside another; 1-Navifusa sp.; m Ostiana microcystis; $\mathrm{n}$ - Polysphaeroides filiformis; o - Caudosphaera expansa; $\mathrm{p}$ unnamed filamentous form; $\mathrm{q}$ - Jacutionema solubila; $\mathrm{r}$ - carbonaceous fragments of the problematic macrofossil Parmia anastassiae; $\mathrm{s}$ - Glomovertella eniseica; $\mathrm{t}$ -

Trachyhystrichosphaera aimika; $\mathrm{u}$ - unnamed form with numerous processes arising from one hemisphere; v - Prolatoforma aculeata. A-k come from the upper assemblage, and 1-v from the lower assemblage of Vychegda Formation. Single scale bar $=50 \mu \mathrm{m}$, double bar $=100 \mu \mathrm{m}$. 
Figure 1 revised

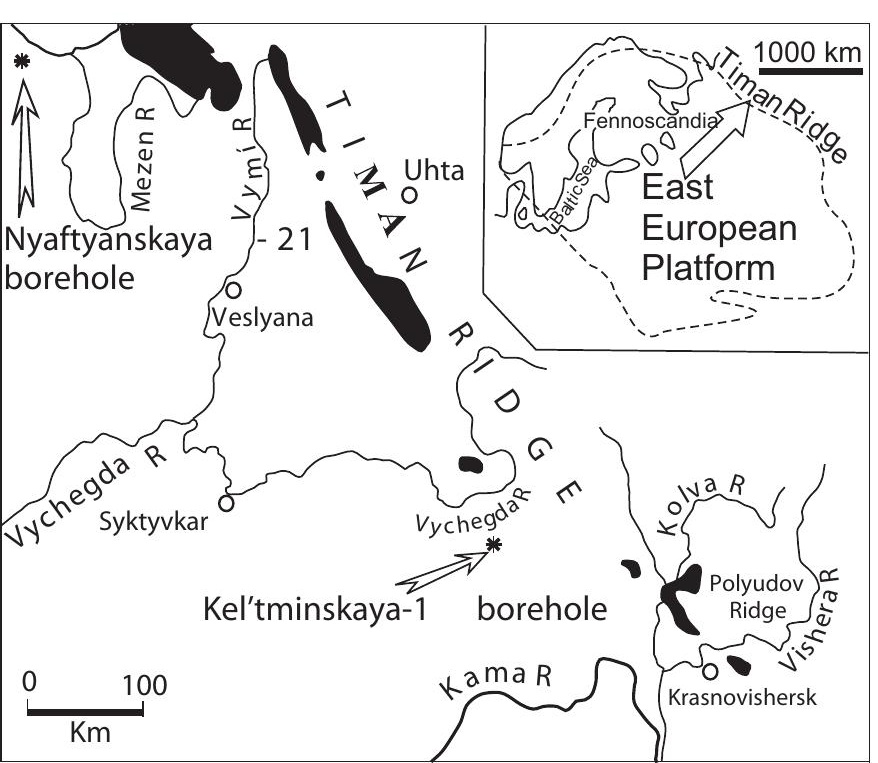




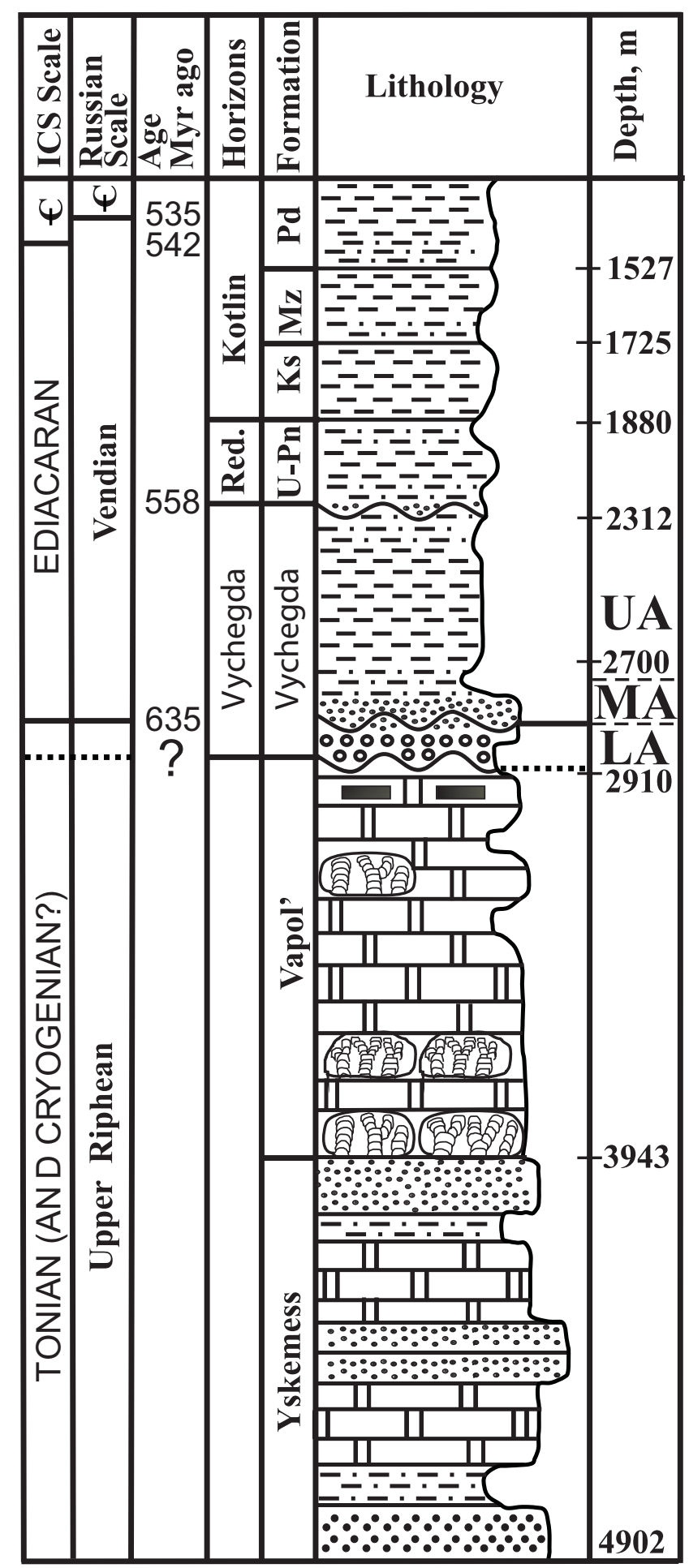

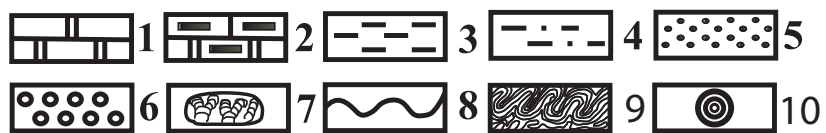




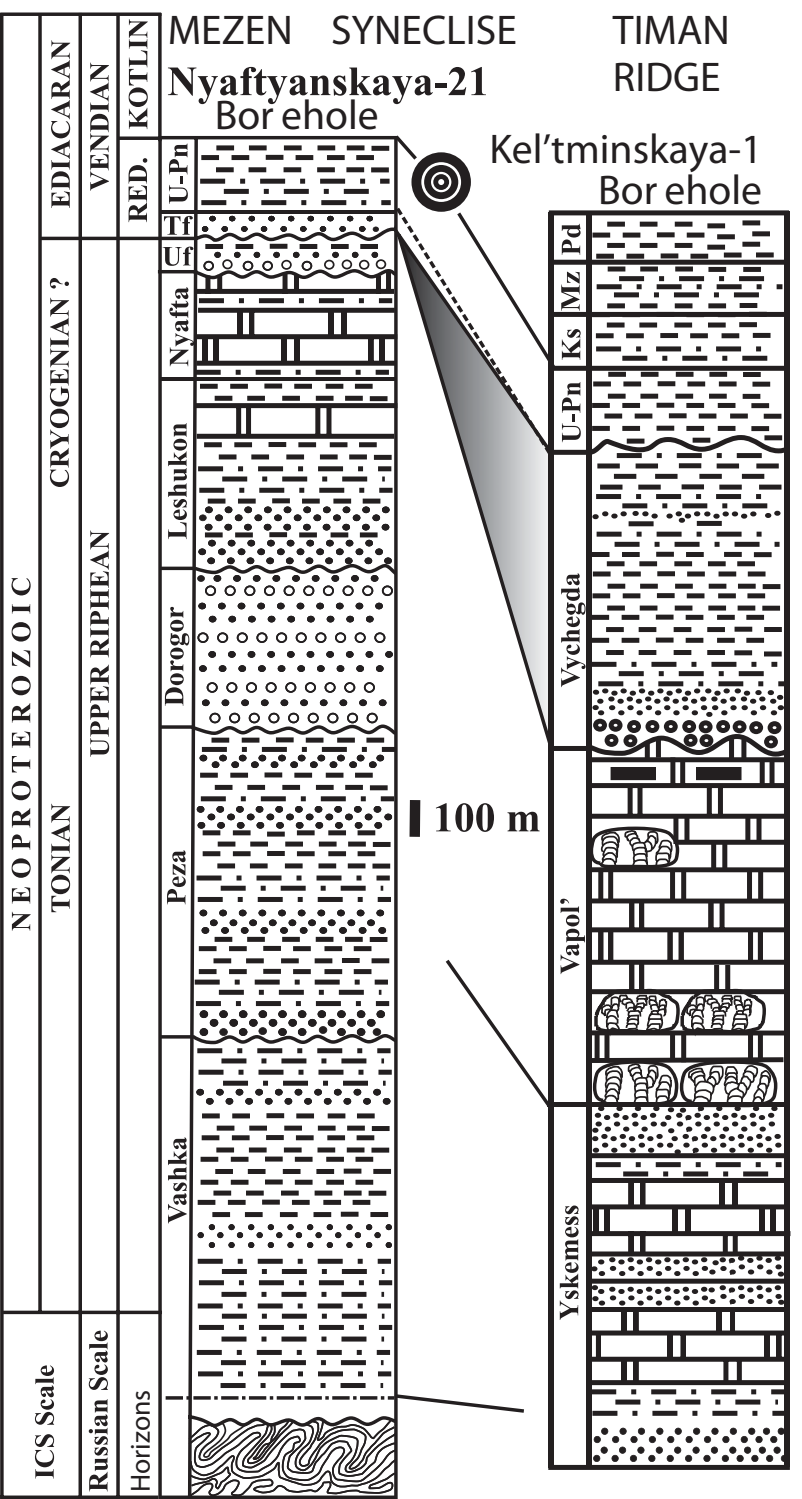


